\title{
Adult Gland Derived Stem Cells (Gdscs); Potentials, Hurdles and Expectations
}

\author{
Salem $\mathbf{H}^{1 *}$, Ismail $\mathbf{M}^{1}$ and Seify $\mathbf{H}^{2}$ \\ ${ }^{1}$ Department of Plastic Surgery, KAFM, Cairo University, Egypt \\ ${ }^{2}$ Department of Plastic Surgery, UCLA-Harbor, California, USA
}

\begin{abstract}
In the past decades, a progressively escalating international pool of information regarding stem cells research and their applications was periodically accumulating. Among the famous, well-established stem cells sources and lines, a new source appeared that was derived from the adult glands.
\end{abstract}

Despite the long time theories speculating that the adult glands, as most of adult tissues, harbor their own stem cell pools, only recently those cells were isolated, characterized and successfully propagated from the glands.

Although some of them are still in the immature phase of research, but within a few years, the newly identified glands derived stem cell lines proved their potency in multiple fields, with the relative ease of their harvesting and propagation compared to other sources.

For the first time in literature, a definitive focus is given in this review to the adult gland derived stem cells, in a trial to understand and track their potentials as a new innovative form of stem cells for future applications.

Keywords: Glands; Stem cells; Regenerative medicine

\section{Introduction}

Adult (non-embryonic, postnatal somatic) stem cell is an undifferentiated cell found among differentiated cells in a tissue or organ that has the ability to renew itself (Multipotency) [1].

Growing attention has focused on organ specific adult stem cells, both to better understand how injured organs regenerate and as a therapeutic target for disease modulation $[2,3]$. It was originally thought that the adult mammalian stem cells were only present in organs such as blood, skin, gut, testes and the respiratory tract, which have high cell turnover rates. It was proven, however, that most if not all, adult organs contain stem cells, or at least can produce stem cells in culture $[4,5]$.

Adult stem cells derived from the bone marrow have been used for more than 40 years for treatment of hematological disorders. Since the identification of the first adult mouse bone marrow stem cells, it was shown that transplantations of the Haemopoeitic stem cells (HSCs) isolated from the bone marrow, could reconstitute the depleted bone marrow following irradiation [6].

Following this discovery, Friedenstein in 1974 noticed another cell type in the bone marrow explants, initially called the fibroblast colonyforming cells, now referred to as Marrow-derived or Mesenchymal Stem Cells (MSCs) [7]. In contrast to HSCs, MSCs can be grown more easily and can differentiate into mesoderm-derived tissues, while HSCs can re-constitute the haemopoeitic system. MSCs can be selectively grown into bone cells (osteocytes) [8], fat cells (adipocytes) [9] and cartilage cells (chondrocytes) [10] which made them an attractive choice for bone and cartilage tissue engineering as autologous transplants $[11,12]$. Moreover, they are now considered a routine medical procedure in treating leukemia patients in addition to HSCs [13].

The discovery of adult stem cells in the CNS was first inferred from the evidence of neuronal turnover in the olfactory bulb and hippocampus $[14,15]$. This discovery of what was called afterwards Neuronal Stem cells (NSCs) in an organ that was previously thought to be largely immutable following embryogenesis, opened new avenues of investigation in regenerative medicine concerning the role of such stem cells in Parkinsonism and Alzheimer's diseases [16,17].

In this review, we highlight some of the particularly promising sources of potent adult stem cells; the glandular tissues derived ones, elucidating their importance and future potentials in diseases management.

\section{Pancreas Derived Stem Cells (PSCs)}

Pancreas is a unique organ with a closely integrated admixture of exocrine and endocrine tissues. In the view of the success of pancreatic islet transplantation trials, especially after development of the Edmonton Protocol in 1990 and its publish in 2000 [18,19], betacell stem or progenitor cells were seen as a potential source for the preparation of a transplantable insulin-producing tissue [20].

Thus, several adult islet/beta-cell progenitors derived from pancreas, liver, and bone marrow, were studied [21]. Moreover, it was proven that the pancreas have Pancreas-derived Multipotent Precursor cells PMPs as described by Seaberg, that express both neural and pancreatic precursor markers [22]. Possible progenitors have been hypothesized to reside within the pancreatic ductal epithelium [23], acinar tissue and/or pancreatic small cells [24].

Although the transplantation of islet grafts containing higher numbers of ductal epithelial cells results in a better clinical outcome [25], several in vitro attempts to isolate beta-cell progenitors thought

*Corresponding author: Haitham Salem, Associate Lecturer at Plastic Surgery Department, KAFM, Cairo University, Egypt, Tel: +20 2 35676105; E-mail: drsalemhaitham@gmail.com

Received June 15, 2014; Accepted August 27, 2014; Published August 29, 2014

Citation: Salem H, Ismail M, Seify H (2014) Adult Gland Derived Stem Cells (Gdscs); Potentials, Hurdles and Expectations. J Stem Cell Res Ther 4: 228. doi:10.4172/2157-7633.1000228

Copyright: ( 2014 Salem H, et al. This is an open-access article distributed under the terms of the Creative Commons Attribution License, which permits unrestricted use, distribution, and reproduction in any medium, provided the original author and source are credited. 
to reside within the human ductal and acinar epithelium have been inconsistent till today [26-29].

Earlier, Choi followed by Seeberger proved that stem cells isolated from different parts of the adult pancreas are able to cross-lineage boundaries in vitro, in addition to its differentiation into endodermal and mesodermanl cells $[30,31]$. Also, the exocrine acinary part of the pancreas, particularly periacinary or dedifferentiated acinary cells, was considered to be another source of stem cells [32].

Surprisingly afterwards, Kruse et al. proved that cells isolated from the exocrine parts of the adult pancreas have a remarkable ability for self-renewal together with a great plasticity potential. These cells were able to differentiate into various cell types representing all three germ layers. Those cells demonstrated (i) typical stem/progenitor cell markers (Alk. Phos., SSEA-1, Oct-4, CD9, Nestin, Pax6, CD44, alphafetoprotien), (ii) have the potential to differentiate into lineages of all three germ layers in vitro, (iii) clonal analysis revealed that even cell lines derived from a single cell have stem/progenitor cell properties, (iv) external stimuli can activate the generation of certain cell types (e.g: alpha-smooth muscle actin upon retinoic acid stimulation). Those cells were called Pancreatic Stellate Cells based on their morphological appearance or more commonly Pancreatic Stem Cells (PSCs) [33,34].

In a study that compared two stem cell populations (Skin versus Pancreatic stem cells) concerning their phenotypic characterization, stem cells characteristics and differentiation across lineage boundaries, it was surprisingly proved that the Skin-derived human adult stem cells share many features with the Pancreatic-derived human stem cells, this opened the gate for a new way of tackling those PSCs concerning their medical applications and their potential role in skin regeneration and wound healing [35]. In this view, those cells were then successfully tested for their potentials in wound healing [36], and for their ability to enhance the wound vicinity vascularity [37]. Also they were used for defective myocardial tissue repair proving a superior intra-myocardial homing of PSCs in comparison to MSCs therapy [38].

\section{Salivary Glands Stem cells}

Salivary glands are derived from the endoderm and the ectoderm that participate in organogenesis [39]. They consist of many cell types, including duct epithelium, acinar, mesenchymal, and neuronal cells [40]. Acinar cells secrete amylase into the digestive tract. This feature resembles the pancreatic exocrine system. Moreover, Salivary glands have been described as a source of stem cells in mice and rats following tissue damage $[41,42]$ and there have been experimental evidences that stem cells can be isolated from intact, non-damaged rat submandibular glands [43]. The existence of salivary gland stem cells has been postulated, although it remained unclear in which compartment of the gland they reside. Some authors suggested the intercalated ducts, whereas others favored the theory that MSCs are generally present in a perivascular niche [44].

In 2008, Rotter et al. [45] published the first paper to describe the isolation and characterization of adult human stem cells from normal parotid gland, these cells followed an amplification period of three to five passages.

As a trial to salvage the function of the Salivary gland specially in patients with head and neck irradiation, Bone marrow-derived stem cells (BMCs) were previously suggested as an easy accessible source for multipotent stem cells that could potentially transdifferentiate and/ or repair other non-hematopoietic organs [46-49], including salivary glands [50].
However, the use of BMCs in solid tissue repair is surrounded by controversies and limited effects. Transplantation of salivary gland stem cells was then proven to be a more adequate and an elegant way for therapy after successful isolation of stem cells from both human Parotid and submandibular glands [51].

Salivary gland cancers are relatively rare but constitute a highly significant public health issue due to the lack of effective treatments. In particular, patients with mucoepidermoid carcinoma or adenoid cystic carcinoma, the two most common salivary malignancies, have low long-term survival rates due to the lack of response to current therapies. Considering the role of Cancer Stem Cells (CSCs) in resistance to therapy with other tumor types, it is possible that this unique subpopulation of salivary gland stem cells is involved in the resistance of salivary gland tumors to treatment [52]. A deeper understanding of the underlying cellular biomechanics of the salivary glands and the potential of their stem cells may be a good option to treat post-tumors radiation-induced Xerostomia [53].

Due to their large number and superficial distribution in the labial mucosa, Minor salivary glands were recently proposed as an easily accessible source of adult stem/progenitor cells for regenerative therapies of glandular organs with parenchymal pathology [54]. In a novel study, pulse chase strategy allowed the identification of slow cycling, label retaining cells (LRC) of minor salivary glands that preferentially localize in the basal layer of the lower excretory duct, with few in the acini possessing stem cells characteristics. Engraftment of isolated salivary glands LRC in vivo demonstrated their ability to differentiate into CK5 (basal layer marker) and CK8 (luminal layer marker) positive structures [55].

Still, in the salivary glands research field, a single stem cell has not been identified that gives rise to all epithelial cell types within the gland. It is also not known whether a number of different lineage-biased stem cell populations or subtypes exist and how these differ from progenitor cells $[56,57]$.

\section{Sweat Glands Stem cells}

Skin is a readily accessible tissue for the isolation of adult autologous stem cells in contrast to most of the other tissues. The human body is covered with several million sweat glands. Two major types of sweat glands exist in the Human skin; eccrine and apocrine. The eccrine glands, which are widely distributed over the human body, have ducts that open directly onto the skin surface enabling them to secrete water and salts. In contrast, the apocrine sweat glands, which are present in hairy areas, are appendages of the hair follicle and release their fluid through the follicle's orifice. In addition, apocrine sweat glands shed off their necrotic cell parts in the form of an oily substance [58,59].

Extensive Lineage tracing with transgenic mice lines has been used to track epithelial progenitors and their progeny $[60,61]$. Recently, the existence of multipotent and unipotent progenitors in the sweat glands was proven using transgenic mice [62], and through tracing the Nestinpositive multipotent stem cells directly isolated from human sweat glands specimens [63].

Former studies using lineage tracing and mouse models proved the role played by both the epidermis and the hair follicles stem cells contributing in the wound repair [64-68].

Due to the abundance of sweat glands in relation to hair follicles in the majority of human skin areas, it has been hypothesized that another source of progenitors and/or stem cells within the sweat apparatus (duct and gland) can contribute to the skin wound repair [69-71]. 
Interestingly, new mouse models permitted definitive assessment of the source of stem cells in wound healing process. Marked cells from the eccrine sweat ducts migrated upward to repair the epidermis within 3 days after a superficial scratch wound. Intraepidermal sweat ducts were reconstructed within 2 weeks. Notably, these reconstructed ducts were derived from cells of the sweat apparatus and not the epidermis. Moreover, only basal progenitors within the sweat ducts, and not the secretory portion of the glands, responded and proliferated to repairing the duct orifice after injury with restoration of sweating [62]. These results provided compelling evidence supporting the notion that the sweat duct is the growth center which repairs the ductal orifice extending through the epidermis to the skin surface [72].

Another study readdressed this issue using the human skin. By immunohistochemistry and computer-assisted three-dimensional reconstruction, researchers concluded that eccrine sweat glands contribute significantly to the reepithelialization after partial-thickness wounds. This opened the gate for enormous wide range potential clinical applications, namely in cases of extensive burns and massive skin loss [73].

In the last decade, in vivo transplantation had been used to assess the regenerative potential at a single-cell level for various ectodermal appendages as a trial for an innovative management of burns. Intriguingly, despite their unipotent behavior in the adult gland, when myoepithelial cells are purified from adult sweat glands, they recreate the adult sweat glands. These findings suggest that the myoepithelial cells retain multipotent (bipotent) potential that can be unleashed when challenged to de novo morphogenesis [72].

\section{Mammary Gland Stem Cells (MaSCs)}

Over 50 years ago, researchers postulated the existence of multipotent mammary stem cells due to the fact that mammary epithelium is able to undergo multiple rounds of proliferation, differentiation and apoptosis with pregnancy. Experiments revealed that neither the developmental state nor the reproductive history of the gland had a significant impact on the longevity of the mammary transplants [74,75].

The study of mammary stem cells biology in the mouse actually began with the pioneering studies of Deome et al. when a serial transplantation of mammary tissues into the cleared mammary fat pad of syngenic mice was done [76-78]. They demonstrated that the adult mammary gland contained cells that were capable of reconstituting a complete and functional mammary gland with normal ductal tree and hormonal response in the epithelium-divested fat pad of the transplant recipient [79].

Subsequent studies supported the old notion of the cells residing throughout the entire intact epithelial tree, that are capable of regenerating an entire mammary gland, and that they persist through various developmental states [80].

A strategy was used to isolate MaSCs relied upon a feature believed to be a key mechanism of DNA replication during stem cells division. During their division, certain adult stem cells preferentially retain one of their DNA strands throughout multiple divisions in order to protect against the formation of deleterious mutations that occur with replication $[81,82]$. By performing pulse chase experiments with DNA labels, Smith et al. showed that there was a population of cells within the mammary gland, which retained their DNA label through asymmetric segregation of DNA strands. These cells were still actively dividing and featured stem cell characteristics [83].
However, It was not until 2006 that self-renewing multipotent stem cells were successfully isolated from the mammary gland by fluorescent activated cell sorting (FACS), detecting the cell surface markers CD24 (heat stable integrin) and CD29 ( $\beta 1$-integrin) in mouse mammary tissue $[84,85]$. CD49f ( $\alpha 6$-integrin) and EpCAM positive cells were then isolated from the human mammary tissues $[86,87]$. The CD29 protein is not just a surrogate marker for MaSCs but is actually functionally important, as CD29 ablation in the basal compartment is reported to effectively reduce MaSC activity [88].

Another study showed that with the use of a GFP reporter driven by the s-SHIP promoter, GFP+ replicating active MaSCs can be identified in cap cells at puberty and basal alveolar bud cells in pregnancy, but not in adult virgin animals, or in mammary tissues during lactation or involution stages [89].

A major limitation of both the morphological and the label retention methods is that they do not allow easy isolation of large numbers of pure MaSC populations for use in in vitro or in vivo assays [90]. With respect to the human mammary gland, identification of authentic MaSCs is considered a greater challenge due to the difficulty in obtaining normal tissue samples and the lack of an ideal in vitro reconstitution system. Nevertheless, various attempts have been made to characterize human MaSCs both in vitro and in vivo [91].

As a trial to unravel this mystery, taking into consideration the analogous embryonic development of both mammary glands and sweat glands from ectodermal appendages [92], a latest study applied the already established isolation and propagation protocols used for salivary and sweat gland-derived stem cells, to the harvest of MaSCs from the mammary tissue of human donors via conventional cell culture, using a similar way to the older technique of breast milk-derived stem cells [93], demonstrating a consistent isolation, propagation and identification of CK19+ nestin-positive MaSCs and with characterization of the cell populations derived from both genders [94].

\section{Lacrimal Gland Derived Stem Cells}

A relatively new and particularly unique field of stem cells research due to the rarity of the needed in vitro human specimens for study.

The lacrimal gland is made up of acini, ducts, nerves, myoepithelial cells, and plasma cells secreting a tear film interface between the external environment and the ocular surface [95]. Approximately $80 \%$, of the gland are the acinar cells, which secrete electrolytes, water, and proteins [96].

Dry eye syndrome (DES) is caused by inadequate quantity or quality of tears. Although there are numerous well-known tear substitutes that can be used to temporarily lubricate the eye, there is actually no curative treatment for the dry eye syndrome [97,98]. Cell therapy involving replacement of the gland is a promising alternative for providing long-term relief to such patients [99].

After an experimentally induced inflammation, Samantha et al previously reported an increasing number of stem/progenitor cells present in the murine lacrimal gland during the repair phase. These cells were found to be nestin positive, and some of them expressed $\alpha$-smooth muscle actin ( $\alpha$-SMA), suggesting a common source of stem cells between myoepithelial cells and acinar cells in the lacrimal gland $[100,101]$.

Shortly afterwards, the same research group suggested that an Epithelial-Mesenchymal transition (EMT) is induced during the repair of the lacrimal gland to generate Mesenchymal stem cells (MSCs) 
that migrate to the site of injury initiating repair, followed then by the activation of Mesenchymal-Epithelial Transition (MET) to form acinar and ductal epithelial cells with the contribution of several transcription factors (Snai1, Snai2, ZEB1 and ZEB2) [102-104].

While lacrimal gland cultures from animal sources are well established [105,106], similar evidence from humans is limited. Thus, a newly established study documented what could be the first successful method of isolating and culturing functionally competent fresh human lacrimal gland cells, using a cocktail of collagenase and hyaluronidase with Matrigel substrate. The established cultures were maintained in vitro for 30-35 days, providing evidence for the presence of putative stem cells in the tissues that express ABCG2 and ALDH1 stem cell markers. In addition, the cultures lead to the formation of spheres similar to the well documented Salispheres [106] and Prostaspheres [107] in their cellular organization $[99,108]$.

The promising discovery of stem cells in the lacrimal gland is an important finding on the path to salvage a damaged gland in the future.

\section{Major Debates and Hurdles}

\section{Neo-genesis versus self-duplication of Pancreas derived stem cells}

It is worth to be mentioned that in the past several years a wealth of new data on the origin of differentiated cells in the embryonic and adult pancreas have been accumulating. Before the era of genetic lineage tracing, we were inclined to accept the histological evidence of neogenesis, particularly following injury [109]. This view became more skeptical and extremely debatable once the lineage tracing studies revealed that the pre-existing $\beta$-cell could account for both growth and regeneration $[110,111]$. It was shown that Ductal cells do not generate endocrine cells following streptozotocin (STZ)-induced $\beta$-cell ablation, Solar and colleagues failed to observe $\beta$-cell regeneration from ductal cells following alloxan-mediated $\beta$-cell ablation and subsequent treatment with epidermal growth factor and gastrin [112].

Moreover, compelling opposing evidence showed that pancreatic duct ligation (PDL) could induce Ngn3-dependent islet neogenesis. Ngn3 is not normally expressed in the adult pancreas, even after pancreatectomy. As a regulator of pancreatic endocrine formation, Ngn3 expression was shown to be initiated in duct cells, and persisted into new islet cells, boosting the insulin dependent $\beta$-cells formation. $[113,114]$. Combining techniques, Chung et al. reported a recovery of $\beta$-cell mass within two weeks after alloxan administration when combined with PDL [115]. However, the origin of $\beta$ cells in this socalled "alloxan+PDL" model was not tested through the use of genetic lineage tracing studies [116].

Two major concerns remain; first, not knowing the exact triggering stimulus of the endocrine differentiation in utero or in adults following PDL makes it hard to design rational culture conditions for optimization. Second, most pancreatic cell preparations are contaminated by preexisting $\beta$-cells. Survival and expansion of those $\beta$-cells during culture will make it hard to detect true neogenesis. This might imply that a phenomenon widely interpreted as neogenesis is actually nothing but an expansion of the pre-existing islet cells in vitro, or else that islet precursors express a marker, NCAM, generally assumed to be specific to the differentiated endocrine cells [117].

\section{Radiotherapy and Salivary Glands}

Regretfully, most of the head and neck cancer patients are of old age and have been suggested to respond dramatically to the deleterious effects of radiation on the salivary glands [118].

Moreover, a reduction in the salisphere-forming capability of cells from salivary gland of old age is reported [119]. Combined with the unfortunate fact that prior to radiotherapy, only a small piece of tissue from the patient could be obtained makes it essential to multiply the cells before transplantation, and it is therefore of utmost importance to solve the problem of lacking protocols that safely permit this.

Current in vitro culture, self-renewal, and differentiation assays open new possibilities for the screening of novel factors and genes that may be useful tools for stem cells amplification. The involvement of Notch signaling pathway has been implicated in postnatal salivary gland development and regeneration, and the protective effects of both KGF treatment and the transiently activated Wnt pathway against radiation-induced damage of the salivary glands have been suggested $[120,121]$

Although consensus is that some form of the salivary gland cellular therapy is feasible to increase the quality of life of head and neck cancer patients particularly post radiotherapy, considerable hurdles facing the development of a cellular therapy based upon a prolonged in vitro culture that can affect the expression of cell surface markers, which define this hierarchy [122].

Generally, Radiotherapy treatment schedules with curative intent last between 5 and 7 weeks, not including the extra time required for biopsy of the salivary glands pre-treatment. In an ideal situation, transplantation should be performed as soon as possible after radiotherapy, before tissue fibrosis kicks in, which is likely to be detrimental to cell engraftment. Thus, cells will probably be cultured briefly during this 5-7 weeks period and then undergo cryopreservation till the desired time point. Both manipulations techniques carry their own challenges $[53,123]$.

\section{Mammary gland stem cells (MaSCs) and Tumor-genesis}

Studies using avian retrovirus-mediated introduction of oncogenes into a small subset of somatic mammary cells suggest that polyoma middle $\mathrm{T}$ antigen (PyMT) preferentially transform stem/progenitor cells. These observations suggest that stem/progenitor cells in the mammary gland may be especially susceptible to oncogenic transformation. Whether more differentiated cells may also be transformed by particular oncogenes is actively debated; it is presently unclear whether stem cells or differentiated mammary cells are more susceptible to transformation by individual oncogenes [124].

A common long time debate with all forms of stem cells, but

\begin{tabular}{|c|c|}
\hline CSC Marker & \begin{tabular}{c} 
Associated Tumor Type(s) \\
\hline CD133
\end{tabular} \\
\hline CD44 & $\begin{array}{c}\text { Brain, Colon, Liver, lung, Ovarian, pancreas, prostate } \\
\text { Coloread and neck squamous cell carcinoma, } \\
\text { Liver, ovarian, Prostate }\end{array}$ \\
\hline CD24** & Breast, Pancreas \\
\hline CD90 & Breast, liver, Lung \\
\hline CD34 & AML, Lung \\
\hline CD117 & Lung, Ovarian \\
\hline CD20 & Melanoma \\
\hline ALDH & Breast, Liver \\
\hline
\end{tabular}

** CD24 is a common marker between normal Mammary gland stem cells (MaSCs) and Cancer stem cells (CSCs)

Table 1: Commonly used markers for CSCs as suggested by Fabian et al. with established breast tissue markers seen among them [127]. 
Citation: Salem H, Ismail M, Seify H (2014) Adult Gland Derived Stem Cells (Gdscs); Potentials, Hurdles and Expectations. J Stem Cell Res Ther 4: 228. doi:10.4172/2157-7633.1000228

Page 5 of 8

\begin{tabular}{|c|c|c|c|}
\hline Glandular cell source & Culture type & Suggested markers + & Reference \\
\hline Pancreas & Monolayer & $\begin{array}{ll}\text { - } & \text { Ductal cell: CAll and CK19 } \\
\text { - } & \text { Endocrine cell: PDX-1 and Ngn3 and GLUT1, VDCC } \\
\text { - } & \text { Expansion: SMA and Vimentin } \\
\text { - } & \text { *Stemness: Oct4, ABCG2, SCF and CD133 }\end{array}$ & Zhang et al. [128] \\
\hline Salivary & $\begin{array}{l}\text { Salisphere } \\
\text { Monolayer }\end{array}$ & $\begin{array}{l}\text { - } \quad \text { CD34, CD117, ALDH, CD90, CD44 } \\
\text { - } \quad \text { CD49f, CD29, CD24, CD133 }\end{array}$ & Pringle et al. [53] \\
\hline Sweat & Monolayer & $\begin{array}{ll}\text { - } & \text { Gland: NKAa, ATP1a1 } \\
\text { K19 } \\
\text { - } \quad \text { Luminal cell: K8, K18 } \\
\text { - } \quad \text { Myoepithelial cell: K5, K14 } \\
\text { *Stemness: Nestin, la6, Oct4, SOX2 }\end{array}$ & $\begin{array}{l}\text { Lu et al. [62] } \\
\text { Nagel et al. [63] }\end{array}$ \\
\hline Mammary & $\begin{array}{c}\text { Monolayer } \\
\text { Mammosphere }\end{array}$ & $\begin{array}{l}\text { - } \quad \text { Mammary cell: CD19, CALLA, ESA, MUC-1 } \\
\text { - } \quad \text { Duct cell: CD24 } \\
\text { - } \quad \text { Mammospheres: CD105 } \\
\text { *Stemness: Nestin, CD9, CD29, CD44, and CD81 }\end{array}$ & $\begin{array}{l}\text { Hebbard et al. [129] } \\
\text { Liu et al. [126] } \\
\text { Richter et al. [92] } \\
\text { Liao et al. [130] }\end{array}$ \\
\hline
\end{tabular}

* Cells show different Stem cell markers (Stemness) throughout different culture passages

+ All gland derived cells showed markers of differentiation to the three germ layers

Table 2: Summary of the suggested cellular markers of different types of gland derived stem cells by some authors.

particularly crucial with MaSCs is that the normal mammary stem cells share the cancer stem cells (CSCs) several important properties, including the ability to self-renew and to undergo differentiation (Table 1). It was proven that the transcriptional programs that control luminal and basal lineage identity in the normal mammary epithelium as well as the progenitor and stem cell function, are active in breast cancers and show distinct associations with different disease subtypes. Also active in some tumors is the epithelial to mesenchymal transition (EMT) program, which endows carcinoma, cells with mesenchymal as well as stem cell traits [125].

There has been lots of controversy about the nature of the cells that serve as targets of transformation [126]. Therefore, it is of an urgent importance to properly identify, label and characterize the MaSCs and study their differentiation potentials in response to various deleterious stimuli as a trial to understand the pathogenesis of breast tumors, in order to provide innovative solutions for breast cancers, meanwhile avoiding transfusing patients with a tumor generating time bomb.

\section{Future Perspectives}

Due to expanding nature of the field and the accumulation of vast new information about them, the need is exponentially growing to focus separately on the adult gland-derived stem cells as a continuous supply of stem cells and to our knowledge; this is the first review that takes that matter into consideration.

The available different forms of adult gland derived stem cells are not fully understood regarding their mode of action, characters, fully discriminating individual type markers (Table 2) and longterm effects, which is yet to be investigated. Nevertheless, they offer possible new supply for treatment of multiple medical problems (eg: B-cell deficiency, lacrimal glands dysfunction, salivary tumors, burns and skin regeneration). Still, the techniques and methods for practical application of such innovative treatments are far from optimization, which makes it invaluable to have more focused future trials on exploring their potentials and to optimize their medical use.

\section{Acknowledgment}

The first author would like to express all due respect to fellow colleagues and mentors in Germany; Prof. Dr. H-G Machens, Prof. Dr. C Kruse, Dr. D Rapoport, Dr. P Ciba, Dr. A Richter and S Nagel. Also, all gratitude for the continuous efforts, and the generous support of friends and colleagues at the KAFM, Cairo University, Egypt.

\section{References}

1. Metcalfe AD, Ferguson MW (2008) Skin stem and progenitor cells: using regeneration as a tissue-engineering strategy. Cell Mol Life Sci 65: 24-32. [PubMed]

2. Tumbar T, Guasch G, Greco V, Blanpain C, Lowry WE, et al. (2004) Defining the epithelial stem cell niche in skin. Science 303: 359-363. [PubMed]

3. Naveiras O, Daley GQ (2003) Stem cells and their niche: a matter of fate. Cell Mol Life Sci 63: 760-766. [PubMed]

4. Raff M (2003) Adult stem cell plasticity: fact or artifact? Annu Rev Cell Dev Biol 19: 1-22. [PubMed]

5. Pelacho B, Mazo M, Gavira JJ, Prósper F (2011) Adult stem cells: from new cell sources to changes in methodology. J Cardiovasc Transl Res 4: 154-160. [PubMed]

6. Mathe G, Amiel JL, Schwarzenberg L, Cattan A, Schneider M (1963) Haematopoietic Chimera in Man after Allogenic (Homologous) Bone-Marrow Transplantation. (Control of the Secondary Syndrome. Specific Tolerance Due to the Chimerism). Br Med J 2: 1633-1635. [PubMed]

7. Friedenstein AJ, Deriglasova UF, Kulagina NN, Panasuk AF, Rudakowa SF, et al. (1974) Precursors for fibroblasts in different populations of hematopoietic cells as detected by the in vitro colony assay method. Exp Hematol 2: 83-92. [PubMed]

8. Ciavarella S, De Matteo M, Cafforio P, Dammacco F, Silvestris F (2008) Mesenchymal stem cells and bone regeneration. Recenti Prog Med 99: 75-82. [PubMed]

9. Schipper BM, Marra KG, Zhang W, Donnenberg AD, Rubin JP (2008) Regional anatomic and age effects on cell function of human adipose-derived stem cells. Ann Plast Surg 60: 538-544. [PubMed]

10. Xu J, Wang W, Ludeman M, Cheng K, Hayami T, et al. (2008) Chondrogenic differentiation of human mesenchymal stem cells in three-dimensional alginate gels. Tissue Eng Part A 14: 667-680. [PubMed]

11. Noth U, Steinert AF, Tuan RS (2008) Technology insight: adult mesenchyma stem cells for osteoarthritis therapy. Nat Clin Pract Rheumatol 4: 371-380. [PubMed]

12. Wang TW, Wu HC, Wang HY, Lin FH, Sun JS (2009) Regulation of adult human mesenchymal stem cells into osteogenic and chondrogenic lineages by different bioreactor systems. J Biomed Mater Res A 88: 935-946. [PubMed]

13. Liu K, Chen Y, Zeng Y, Xu L, Liu D, et al. (2011) Coinfusion of Mesenchymal Stromal Cells Facilitates Platelet Recovery Without Increasing Leukemia Recurrence in Haploidentical Hematopoietic Stem Cell Transplantation: A Randomized, Controlled Clinical Study. Stem Cells Dev 20: 1679-1685. [PubMed]

14. Altman J, Das GD (1965) Autoradiographic and histological evidence of postnatal hippocampal neurogenesis in rats. J Comp Neurol 124: 319-335. [PubMed] 
Citation: Salem H, Ismail M, Seify H (2014) Adult Gland Derived Stem Cells (Gdscs); Potentials, Hurdles and Expectations. J Stem Cell Res Ther 4: 228. doi:10.4172/2157-7633.1000228

15. Altman J, Das GD (1966) Autoradiographic and histological studies of postnatal neurogenesis.l. A longitudinal investigation of the kinetics, migration and transformation of cells incorporating tritiated thymidine in neonate rats, with special reference to postnatal neurogenesis in some brain regions. J Comp Neurol 126: 337-389. [PubMed]

16. Korecka JA, Verhaagen J, Hol EM (2007) Cell-replacement and gene-therapy strategies for Parkinson's and Alzheimer's disease. Regen Med 2: 425-446. [PubMed]

17. Goldman SA (2007) Disease targets and strategies for the therapeutic modulation of endogenous neural stem and progenitor cells. Clin Pharmacol Ther 82: 453-460. [PubMed]

18. Shapiro AM, Lakey JR, Ryan EA, Korbutt GS, Toth E, et al. (2000) Islet transplantation in seven patients with type 1 diabetes mellitus using a glucocorticoid-free immunosuppressive regimen. N Engl J Med 343: 230-238. [PubMed]

19. Ryan EA, Lakey JR, Rajotte RV, Korbutt GS, Kin T, et al. (2001) Clinical outcomes and insulin secretion after islet transplantation with the Edmonton protocol. Diabetes 50: 710-719. [PubMed]

20. Liao YH, Verchere CB, Warnock GL (2007) Adult stem or progenitor cells in treatment for type 1 diabetes: current progress. Can J Surg 50: 137-142. [PubMed]

21. Lechner A, Habener JF (2003) Stem/progenitor cells derived from adult tissues: potential for the treatment of diabetes mellitus. Am J Physiol Endocrinol Metab 284: E259-266. [PubMed]

22. Seaberg RM, Smukler SR, Kieffer TJ, Enikolopov G, Asghar Z, et al. (2004) Clonal identification of multipotent precursors from adult mouse pancreas that generate neural and pancreatic lineages. Nat Biotechnol 22: 1115-1124. [PubMed]

23. Gao R, Ustinov J, Pulkkinen MA, Lundin K, Korsgren O, et al. (2003) Characterization of endocrine progenitor cells and critical factors for their differentiation in human adult pancreatic cell culture. Diabetes 52: 2007-2015. [PubMed]

24. Rooman I, Lardon J, Bouwens L (2002) Gastrin stimulates beta-cell neogenesis and increases islet mass from transdifferentiated but not from normal exocrine pancreas tissue. Diabetes 51: 686-690. [PubMed]

25. Street CN, Lakey JR, Seeberger K, Helms L, Rajotte RV, et al. (2004) Heterogenous expression of nestin in human pancreatic tissue precludes its use as an islet precursor marker. J Endocrinol 180: 213-225. [PubMed]

26. Zulewski H, Abraham EJ, Gerlach MJ (2001) Multipotential nestin-positive stem cells isolated from adult pancreatic islets differentiates ex vivo into pancreatic endocrine, exocrine, and hepatic phenotypes. Diabetes 50: 521-533.

27. Street CN, Lakey JR, Shapiro AM, Imes S, Rajotte RV, et al. (2004) Islet graft assessment in the Edmonton Protocol: implications for predicting long-term clinical outcome. Diabetes 53: 3107-3114. [PubMed]

28. Zulewski $\mathrm{H}$ (2008) Differentiation of embryonic and adult stem cells into insulin producing cells. Panminerva Med 50: 73-79. [PubMed]

29. Yu L, Luo JX, Wei JL, Mu XJ, Ren XX, et al. (2014) Insulin-Producing Acinar Cells in Adult Human Pancreas. Pancreas 43: 592-596. [PubMed]

30. Choi Y, Ta M, Atouf F, Lumelsky N (2004) Adult pancreas generates multipotent stem cells and pancreatic and nonpancreatic progeny. Stem Cells 22: 1070 1084. [PubMed]

31. Seeberger KL, Dufour JM, Shapiro AM, Lakey JR, Rajotte RV, et al. (2006) Expansion of mesenchymal stem cells from human pancreatic ductal epithelium. Lab Invest 86: 141-153. [PubMed]

32. Jensen JN, Cameron E, Garay MV, Starkey TW, Gianani R, et al. (2005) Recapitulation of elements of embryonic development in adult mouse pancreatic regeneration. Gastroenterology 128: 728-741. [PubMed]

33. Kruse C, Kajahn J, PetschnikAE, Maass A, Klink E, et al. (2006) Adult pancreatic stem/progenitor cells spontaneously differentiate in vitro into multiple cell lineages and form teratoma-like structures. Ann Anat 188: 503-517. [PubMed]

34. Danner S, Kajahn J, Geismann C, Klink E, Kruse C (2007) Derivation of oocytelike cells from a clonal pancreatic stem cell line. Mol Hum Reprod 13: 11-20. [PubMed]

35. Kajahn J, Gorjup E, Tiede S, von Briesen H, Paus R, et al. (2008) Skin-derived human adult stem cells surprisingly share many features with human pancreatic stem cells. Eur J Cell Biol 87: 39-46. [PubMed]
36. Salem H, Ciba P, Rapoport DH, Egana JT, Kadry M, et al. (2009) The influence of pancreas-derived stem cells on scaffold based skin regeneration. Biomaterials 30: 789-796. [PubMed]

37. Egaña JT, Danner S, Kremer M, Rapoport DH, Lohmeyer JA, et al. (2009) The use of glandular-derived stem cells to improve vascularization in scaffoldmediated dermal regeneration. Biomaterials 30: 5918-5926. [PubMed]

38. Guldner NW, Kruse C, Sievers H (2011) Textbook of regenerative medicine and tissue engineering.

39. Larson WJ (2001) Human Embryology. (3rdedn), Churchill Living-stone, Edinburgh.

40. Fawcett DW (1986) A Textbook of Histology. (11thedn), Saunders, Philadelphia

41. Okumura K, Nakamura K, Hisatomi Y, Nagano K, Tanaka Y, et al. (2003) Salivary gland progenitor cells induced by duct ligation differentiates into hepatic and pancreatic lineages. Hepatology 38: 104-113. [PubMed]

42. Hisatomi Y, Okumura K, Nakamura K, Matsumoto S, Satoh A, et al. (2004) Flow cytometric isolation of endodermal progenitors from mouse salivary gland differentiate into hepatic and pancreatic lin- eages. Hepatology 39: 667-675. [PubMed]

43. Kishi T, Takao T, Fujita K, Taniguchi H (2006) Clonal proliferation of multipotent stem/progenitor cells in the neonatal and adult salivary glands. Biochem Biophys Res Commun 340: 544-552. [PubMed]

44. Da Silva Meirelles L1, Chagastelles PC, Nardi NB (2006) Mesenchymal stem cells reside in virtually all post- natal organs and tissues. J Cell Sci 119: 22042213. [PubMed]

45. Rotter N, Oder J, Schlenke P, Lindner U, Böhrnsen F, et al. (2008) Isolation and characterization of adult stem cells from human salivary glands. Stem Cells Dev 17: 509-518. [PubMed]

46. Couzin J (2006) Clinical trials. A shot of bone marrow can help the heart Science 313: 1715-1716. [PubMed]

47. Lagasse E, Connors H, Al-Dhalimy M, Reitsma M, Dohse M, et al. (2000) Purified hematopoietic stem cells can differentiate into hepatocytes in vivo. Nat Med 6: 1229-1234. [PubMed]

48. Nishida M, Fujimoto S, Toiyama K, Sato H, Hamaoka K (2004) Effect of hematopoietic cytokines on renal function in cisplatin-induced ARF in mice. Biochem Biophys Res Commun 324: 341-347. [PubMed]

49. Orlic D, Kajstura J, Chimenti S, Jakoniuk I, Anderson SM, et al. (2001) Bone marrow cells regenerate infarcted myocardium. Nature 410: 701-705. [PubMed]

50. Lombaert IM, Wierenga PK, Kok T, Kampinga HH, de Haan G, et al. (2006) Mobilization of bone marrow stem cells by granulocyte colony-stimulating factor ameliorates radiation-induced damage to salivary glands. Clin Cancer Res 12 1804-1812. [PubMed]

51. Lombaert IM, Brunsting JF, Wierenga PK, Faber H, Stokman MA, et al. (2008) Rescue of Salivary Gland Function after Stem Cell Transplantation in Irradiated Glands. PLoS One 3: e2063. [PubMed]

52. Adams A, Warner K, Nör JE (2013) Salivary gland cancer stem cells. Ora Oncol 49: 845-853. [PubMed]

53. Pringle S, Van Os R, Coppes RP (2013) Concise review: Adult salivary gland stem cells and a potential therapy for xerostomia Stem Cells 31: 613-619. [PubMed]

54. Andreadis D, Bakopoulou A, Leyhausen G, Epivatianos A, Volk J, et al. (2014) Minor salivary glands of the lips: a novel, easily accessible source of potentia stem/progenitor cells. Clin Oral Investig 18: 847-856. [PubMed]

55. Zhang H, Boddupally K, Kandyba E, Kobielak K, Chen Y, et al. (2014) Defining the localization and molecular characterisitic of minor salivary gland label retaining cells. Stem Cells 32: 2267-2277. [PubMed]

56. Lombaert IM, Knox SM, Hoffman MP (2011) Salivary gland progenitor cell biology provides a rationale for therapeutic salivary gland regeneration. Ora Dis 17: 445-449. [PubMed]

57. Carpenter GH, Cotroneo E (2010) Salivary gland regeneration Front. Oral Bio 14: 107-128. [PubMed]

58. Sato K, Kang WH, Saga K, Sato KT (1989) Biology of sweat glands and their disorders. I. Normal sweat gland function. J Am Acad Dermatol 20: 537-563. [PubMed] 
Citation: Salem H, Ismail M, Seify H (2014) Adult Gland Derived Stem Cells (Gdscs); Potentials, Hurdles and Expectations. J Stem Cell Res Ther 4: 228. doi:10.4172/2157-7633.1000228

59. Wilke K, Martin A, Terstegen L, Biel SS (2007) A short history of sweat gland biology. Int J Cosmet Sci 29: 169-179. [PubMed]

60. Soriano P (1999) Generalized lacZ expression with the ROSA26 Cre reporter strain. Nat Genet 21: 70-71. [PubMed]

61. Blanpain C, Simons BD (2013) Unravelling stem cell dynamics by lineage tracing. Nat Rev Mol Cell Biol 14: 489-502. [PubMed]

62. Lu CP, Polak L, Rocha AS, Pasolli HA, Chen SC, et al. (2012) Identification of stem cell populations in sweat glands and ducts reveals roles in homeostasis and wound repair. Cell 150: 136-150. [PubMed]

63. Nagel S, Rohr F, Weber C, Kier J, Siemers F, et al. (2013) Multipotent nestinpositive stem cells reside in the stroma of human eccrine and apocrine sweat glands and can be propagated robustly in vitro. PLoS One 8: e78365. [PubMed]

64. Ito M, Liu Y, Yang Z, Nguyen J, Liang F, et al. (2005) Stem cells in the hair follicle bulge contribute to wound repair but not to homeostasis of the epidermis. Nat Med 11: 1351-1354. [PubMed]

65. Levy V, Lindon C, Zheng Y, Harfe BD, Morgan BA (2007) Epidermal stem cells arise from the hair follicle after wounding. FASEB J 21: 1358-1366. [PubMed]

66. Tiede S, Kloepper JE, Bodò E, Tiwari S, Kruse C, et al. (2007) Hair follicle stem cells: walking the maze. Eur J Cell Biol 86: 355-376. [PubMed]

67. Nowak JA, Polak L, Pasolli HA, Fuchs E (2008) Hair follicle stem cells are specified and function in early skin morphogenesis. Cell Stem Cell 3: $33-43$. [PubMed]

68. Snippert HJ, Haegebarth A, Kasper M, Jaks V, van Es JH, et al. (2010) Lgr6 marks stem cells in the hair follicle that generate all cell lineages of the skin. Science 327: 1385-1389. [PubMed]

69. Brouard M, Barrandon Y (2003) Controlling skin morphogenesis: Hope and despair. Curr Opin Biotechnol 14: 520-525. [PubMed]

70. Biedermann T, Pontiggia L, Böttcher-Haberzeth S, Tharakan S, Braziulis E, et al. (2010) Human eccrine sweat gland cells can reconstitute a stratified epidermis. J Invest Dermatol 130: 1996-2009. [PubMed]

71. Pontiggia L, Biedermann T, Böttcher-Haberzeth S, Oliveira C, Braziulis E, et al. (2014) De Novo Epidermal Regeneration Using Human Eccrine Sweat Gland Cells: Higher Competence of Secretory over Absorptive Cells. J Invest Dermatol 134:1735-1742. [PubMed]

72. Lu C, Fuchs E (2014) Sweat gland progenitors in development, homeostasis, and wound repair. Cold Spring Harb Perspect Med. [PubMed]

73. Rittié L, Sachs DL, Orringer JS, Voorhees JJ, Fisher GJ (2013) Eccrine sweat glands are major contributors to reepithelialization of human wounds. Am J Pathol 182: 163-171. [PubMed]

74. Daniel CW, Young LJ, Medina D, DeOme KB (1971) The influence of mammogenic hormones on serially transplanted mouse mammary gland. Exp Gerontol 6: 95-101. [PubMed]

75. Young LJ, Medina D, DeOme KB, Daniel CW (1971) The influence of hos and tissue age on life span and growth rate of serially transplanted mouse mammary gland. Exp Gerontol 6: 49-56. [PubMed]

76. Deome K, Faulkin LJ, Bern H, Blair P (1959) Development of mammary tumors from hyperplastic alveolar nodules transplanted into gland-free mammary fat pads of female C3H mice. Cancer Res 19: 515-520. [PubMed]

77. Faulkin LJ Jr, Deome KB (1960) Regulation of growth and spacing of gland elements in the mammary fat pad of the $\mathrm{C} 3 \mathrm{H}$ mouse. J Natl Cancer Inst 24: 953-969. [PubMed]

78. Daniel CW, Deome KB (1965) Growth of mouse mammary glands in vivo after monolayer culture. Science 149: 634-636. [PubMed]

79. Bruno RD, Smith GH (2012) Reprogramming non-mammary and cancer cells in the developing mouse mammary gland Semin. Cell Dev Biol 23: 591-598. [PubMed]

80. Smith GH, Medina D (1988) A morphologically distinct candidate for an epithelial stem cell in mouse mammary gland. J Cell Sci 90:173-183. [PubMed]

81. Cairns J (2002) Somatic stem cells and the kinetics of mutagenesis and carcinogenesis. Proc Natl Acad Sci USA 99: 10567-10570. [PubMed]

82. Potten CS, Owen G, Booth D (2002) Intestinal stem cells protect their genome by selective segregation of template DNA strands. J Cell Sci 115: 2381-2388. [PubMed]
83. Smith GH (2005) Label-retaining epithelial cells in mouse mammary gland divide asymmetrically and retain their template DNA strands. Development 132: 681-687. [PubMed]

84. Shackleton M, Vaillant F, Simpson KJ, Stingl J, Smyth GK, et al. (2006) Generation of a functional mammary gland from a single stem cell. Nature 439 : 84-88. [PubMed]

85. Stingl J, Eirew P, Ricketson I, Shackleton M, Vaillant F, et al. (2006) Purification and unique properties of mammary epithelial stem cells. Nature 439: 993-997. [PubMed]

86. Eirew P, Stingl J, Raouf A, Turashvili G, Aparicio S, et al. (2008) A method for quantifying normal human mammary epithelial stem cells with in vivo regenerative ability. Nat Med 4: 1384-1389. [PubMed]

87. Macias H, Hinck L (2012) Mammary Gland Development. Wiley Interdiscip Rev Dev Biol 1: 533-557. [PubMed]

88. Taddei I, Deugnier MA, Faraldo MM, Petit V, Bouvard D, et al. (2008) Beta1 integrin deletion from the basal compartment of the mammary epithelium affects stem cells. Nat Cell Biol 10: 716-722. [PubMed]

89. Bai L, Rohrschneider LR (2010) s-SHIP promoter expression marks activated stem cells in developing mouse mammary tissue. Genes Dev 24: 1882-1892. [PubMed]

90. Tiede B, Kang Y (2011) From milk to malignancy: the role of mammary stem cells in development, pregnancy and breast cancer. Cell Res 21: 245-257. [PubMed]

91. Fan Y, Chong YS, Choolani MA, Cregan MD, Chan JK (2010) Unravelling the mystery of stem/progenitor cells in human breast milk. PLoS One 5: e14421. [PubMed]

92. Mustonen T, Ilmonen M, Pummila M, Kangas AT, Laurikkala J, et al. (2004) Ectodysplasin A1 promotes placodal cell fate during early morphogenesis of ectodermal appendages. Development 131: 4907-4919. [PubMed]

93. Cregan MD, Fan Y, Appelbee A, Brown ML, Klopcic B, et al. (2007) Identification of nestin-positive putative mammary stem cells in human breastmilk. Cell Tissue Res 329: 129-136. [PubMed]

94. Richter A, Nissen N, Mailänder P, Stang F, Siemers F, et al. (2013) Mammary gland-derived nestin-positive cell populations can be isolated from human male and female donors. Stem Cell Res Ther 4: 78. [PubMed]

95. Tiffany JM (2008) The normal tear film. Dev Ophthalmol 41: 1-20. [PubMed]

96. Dartt DA (2009) Neural regulation of lacrimal gland secretory processes: relevance in dry eye diseases. Prog Retin Eye Res 28: 155-177. [PubMed]

97. Schaumberg DA, Sullivan DA, Dana MR (2002) Epidemiology of dry eye syndrome. Adv Exp Med Biol 506: 989-998. [PubMed]

98. Gupta N, Prasad I, Himashree G (2008) Prevalence of dry eye at high altitude: a case controlled comparative study. High Alt Med Biol 9: 327-334. [PubMed]

99. Tiwari S, Ali MJ, Balla M, Naik MN, Honavar SG, et al. (2012) Establishing Human Lacrimal Gland Cultures with Secretory Function PLoS One 7: e29458.

100.Zoukhri D, Fix A, Alroy J, Kublin CL (2008) Mechanisms of murine lacrimal gland repair after experimentally induced inflammation. Invest Ophthalmol Vis Sci 49: 4399-4406. [PubMed]

101. You S, Kublin CL, Avidan O, Miyasaki D, Zoukhri D (2011) Isolation and Propagation of Mesenchymal Stem Cells from the Lacrimal Gland. Invest Ophthalmol Vis Sci 52: 2087-2094. [PubMed]

102. Thiery JP, Acloque H, Huang RY, Nieto MA (2009) Review Epithelialmesenchymal transitions in development and disease. Cell 139: 871-890 [PubMed]

103.Franco DL, Mainez J, Vega S, Sancho P, Murillo MM, et al. (2010) Snail1 suppresses TGF-beta-induced apoptosis and is sufficient to trigger EMT in hepatocytes. J Cell Sci 123: 3467-3477. [PubMed]

104. You S, Avidan O, Tariq A, Ahluwalia I, Stark PC, et al. (2012) Role of EpithelialMesenchymal Transition in Repair of the Lacrimal Gland after Experimentally Induced Injury. Invest Ophthalmol Vis Sci 53: 126-135. [PubMed]

105. Rismondo V, Gierow JP, Lambert RW, Golchini K, Feldon SE, et al. (1994) Rabbit lacrimal acinar cells in primary culture: morphology and acute responses to cholinergic stimulation. Invest Ophthalmol Vis Sci 35:1176-1183. [PubMed] 
Citation: Salem H, Ismail M, Seify H (2014) Adult Gland Derived Stem Cells (Gdscs); Potentials, Hurdles and Expectations. J Stem Cell Res Ther 4: 228. doi:10.4172/2157-7633.1000228

106. Ueda Y, Karasawa Y, Satoh Y, Nishikawa S, Imaki J, et al. (2009) Purification and characterization of mouse lacrimal gland epithelial cells and reconstruction of an acinarlike structure in three-dimensional culture. Invest Ophthalmol Vis Sci 50: 1978-1987. [PubMed]

107.Shi X, Gipp J, Bushman W (2007) Anchorage-independent culture maintains prostate stem cells. Dev Biol 312: 396-406. [PubMed]

108. Tiwari S, Ali MJ, Vemuganti GK (2014) Human lacrimal gland regeneration Perspectives and review of literature. Saudi J Ophthalmol 28: 12-18. [PubMed]

109. Murtaugh LC, Melton DA (2003) Genes, signals, and lineages in pancreas development. Annu Rev Cell Dev Biol 19: 71-89. [PubMed]

110. Dor Y, Brown J, Martinez OI, Melton DA (2004) Adult pancreatic beta-cells are formed by self-duplication rather than stem-cell differentiation. Nature 429 : 41-46. [PubMed]

111. Murtaugh LC (2007) Pancreas and beta-cell development: from the actual to the possible. Development 134: 427-438. [PubMed]

112. Solar M, Cardalda C, Houbracken I, Martín M, Maestro MA, et al. (2009) Pancreatic exocrine duct cells give rise to insulin-producing beta cells during embryogenesis but not after birth. Dev Cell 17: 849-860. [PubMed]

113. Xu X, D'Hoker J, Stange G, Bonne S, De Leu N, et al. (2008) Beta cells can be generated from endogenous progenitors in injured adult mouse pancreas. Cell 132: 197-207. [PubMed]

114. Qu X, Afelik S, Jensen JN, Bukys MA, Kobberup S, et al. (2013) Notchmediated post-translational control of $\mathrm{Ngn} 3$ protein stability regulates pancreatic patterning and cell fate commitment. Dev Biol 376: 1-12. [PubMed]

115. Chung $\mathrm{CH}$, Hao E, Piran R, Keinan E, Levine F (2010) Pancreatic $\beta$-cell neogenesis by direct conversion from mature a-cells. Stem Cells 28: 16301638. [PubMed]

116. Kopp JL, Dubois CL, Hao E, Thorel F, Herrera PL, et al. (2011) Progenitor cell domains in the developing and adult pancreas. Cell Cycle 10: 1921-1927. [PubMed]

117. Migliorini A, Bader E, Lickert $\mathrm{H}$ (2014) Islet cell plasticity and regeneration. Mol Metab 3: 268-274. [PubMed]

118. Beetz I, Schilstra C, van der Schaaf A, van den Heuvel ER, Doornaert P, et al. (2012) NTCP models for patient-rated xerostomia and sticky saliva after treatment with intensity modulated radiotherapy for head and neck cancer: The role of dosimetric and clinical factors. Radiother Oncol 105: 101-106. [PubMed]
119. Feng J, van der Zwaag M, Stokman MA, van Os R, Coppes RP (2009) Isolation and characterization of human salivary gland cells for stem cell transplantation to reduce radiation-induced hyposalivation. Radiother Oncol 92: 466-471. [PubMed]

20. Hai B, Yang ZH, Millar SE, Choi YS, Taketo MM, et al. (2010) Wnt/beta-catenin signaling regulates postnatal development and regeneration of the salivary gland. Stem Cells Dev 19: 1793-1801. [PubMed]

121. Hai B, Yang Z, Shangguan L, Zhao Y, Boyer A, et al. (2012) Concurrent transient activation of $\mathrm{Wnt} / \mathrm{B}$-catenin pathway prevents radiation damage to salivary glands. Int J Radiat Oncol Biol Phys 83: 109-116. [PubMed]

122. Palmon A, David R, Neumann Y, Stiubea-Cohen R, Krief G, et al. (2012) High-efficiency immunomagnetic isolation of solid tissue-originated integrinexpressing adult stem cells. Methods 56: 305-309. [PubMed]

123. Hussein SM, Batada NN, Vuoristo S, Ching RW, Autio R, et al. (2011) Copy number variation and selection during reprogramming to pluripotency. Nature 471: 58-62. [PubMed]

124. Lindvall C, Bu W, Williams BO, Li Y (2007) Wnt signaling, stem cells, and the cellular origin of breast cancer Stem Cell Rev 3: 157-168. [PubMed]

125. Granit RZ, Slyper M, Ben-Porath I (2014)Axes of differentiation in breast cancer: untangling stemness, lineage identity, and the epithelial to mesenchymal transition. Wiley Interdiscip Rev Syst Biol Med 6: 93-106. [PubMed]

126. Liu S, Dontu G, Wicha MS (2005) Mammary stem cells, self-renewal pathways, and carcinogenesis. Breast Cancer Res 7: 86-95. [PubMed]

127. Fabian A, Barok M, Vereb G, Szöllosi J (2009) Die hard: are cancer stem cells the Bruce Willises of tumor biology? Cytometry A 75: 67-74. [PubMed]

128.Zhang WJ, Xu SQ, Cai HQ, Men XL, Wang Z, et al. (2013) Evaluation of islets derived from human fetal pancreatic progenitor cells in diabetes treatment Stem Cell Res Ther 4: 141. [PubMed]

129. Hebbard L, Steffen A, Zawadzki V, Fieber C, Howells N, et al. (2000) CD44 expression and regulation during mammary gland development and function. J Cell Sci 113: 2619-2630. [PubMed]

130. Liao MJ, Zhang CC, Zhou B, Zimonjic DB, Mani SA, et al. (2007) Enrichment of a population of mammary gland cells that form mammospheres and have in vivo repopulating activity. Cancer Res 67: 8131-8138. [PubMed] 